\title{
Territórios da financeirização urbana
}

\author{
Daniel de Mello Sanfelici \\ Universidade Federal Fluminense
}

\section{revista}

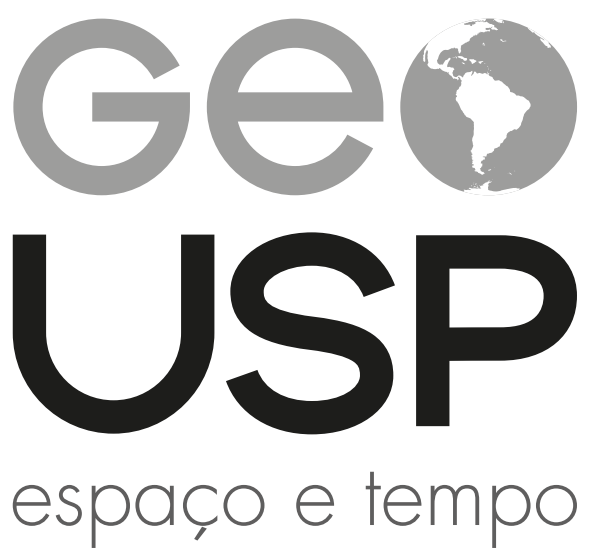

Volume $23 \cdot n^{\circ} 3$ (2019)

ISSN 2179-0892 p. $712-714$

Como citar este artigo:

SANFELICI, D. M. Territórios da financeirização urbana. Geousp - Espaço e Tempo (Online), v. 23, n. 3, p. 712-714, dez. 2019, ISSN 2179-0892.

Disponível em: https://www.revistas.usp.br/geousp/article/view/125140. doi: https://doi.org/10.11606/issn.2179-0892.geousp.2019.125140.

\section{(C) $($ i) (2)}

Este artigo está licenciado sob a Creative Commons Attribution 4.0 Licence 


\section{Territórios da financeirização urbana Resenha de Daniel de Mello Sanfelici}

WEBER, Rachel. From boom to bubble: how finance built the new Chicago. Chicago: The University of Chicago Press, 2015.

As análises teóricas acerca da crise subprime estadunidense fundamentadas na perspectiva da economia política crítica colocaram o acento, via de regra, nas macrodinâmicas de funcionamento do capitalismo. Segundo essa perspectiva, haveria no capitalismo uma propensão a gerar excedentes de capital que, não encontrando oportunidades evidentes de lucratividade, entregam-se vorazmente a dinâmicas especulativas de alto risco - até o ponto em que a festa termina, com ondas de falências e recuperações judiciais. Em linhas gerais, foi essa, efetivamente, a história da crise subprime, precedida por um ciclo ascendente marcado por atitudes crescentemente especulativas e irresponsáveis por parte de instituições financeiras e de investidores. $\bigcirc$ estouro da bolha especulativa de imóveis a partir de 2007 deixou um rastro de desequilibrios patrimoniais e familias desabrigadas por execução hipotecária, forçando o governo estadunidense a intervir para evitar um desastre semelhante ao dos anos 1930. Por correta que seja, essa é, entretanto, uma linha argumentativa que, ao proporcionar uma visão do alto, subestima a importância das decisões e estratégias de uma miríade de sujeitos que, no rés-do-chão, efetivamente produzem esses surtos especulativos.

Preencher essa lacuna possivelmente tenha sido o maior mérito de From boom to bubble: how finance built the new Chicago (Do boom à bolha: como as finanças construíram a nova Chicago), de autoria de Rachel Weber, professora de planejamento urbano da University of Illinois, em Chicago. No livro, Weber se dedica a examinar a trama de agentes econômicos que reconfigurou a paisagem urbana do centro de negócios de Chicago (o Loop) durante o boom dos anos 2000, com a construção de uma profusão de novos edifícios corporativos de alto padrão. No centro das indagações da autora está a questão de por quê e como, mesmo dispondo de uma quantidade substantiva de informações sobre a evolução dos preços e das taxas de ocupação dos imóveis, os agentes econômicos do mercado imobiliário local persistiram numa trajetória de investimentos que resultou, do ponto de vista agregado, numa sobreprodução de imóveis comerciais e na consequente queda vertiginosa de seu preço em 2008. As respostas a essas perguntas são dadas em dois níveis ou planos analíticos que se reforçam mutuamente, produzindo uma leitura multiescalar bastante rica do processo de financeirização das cidades.

No plano macroeconômico, Weber entende que a abundância e a facilidade de acesso a crédito é o principal elemento para explicar o surto especulativo dos anos 2000. Por serem atividades que se desenvolvem tipicamente em médio ou longo prazo, a construção e a aquisição de imóveis sempre se caracterizaram por uma dependência substancial de financiamento externo. A existência de bancos e investidores dispostos a adiantar recursos para a construção e a compra dos imóveis é essencial para dar dinamismo ao setor, uma vez que são poucos os empreendedores aptos (ou dispostos) a autofinanciar a construção por um longo período. Contudo, o 
que se verificou ao longo dos anos 2000 foi mais do que um aumento da disponibilidade de crédito: a ampla desregulamentação do mercado financeiro estadunidense nos anos 1990 se combinou com a disseminação de inovações financeiras de grande alcance, como a securitização de ativos imobiliários, ampliando o acesso de construtoras e investidores a um capital global sedento por novas oportunidades de investimento num cenário de baixas taxas de juros reais. Aqui, Weber se alinha com outros na tradição heterodoxa da economia política (de Marx a Minsky) ao atrelar o excesso de produção à abundância de crédito e às posições cada vez mais especulativas assumidas pelos principais atores: construtoras financiando parcela crescente do processo de construção sem a garantia de um comprador final ou de um percentual mínimo de locatários para o imóvel em construção; investidores como fundos imobiliários contraindo dívidas para adquirir edifícios comerciais pouco rentáveis, com a esperança de revendê-los em poucos anos para auferir ganhos de capital; bancos emitindo empréstimos pouco promissores para em seguida securitizá-los e revendê-los a investidores globais na forma dos famigerados commercial mortgage-backed securities (CMBS). Todas essas são práticas conhecidas em cenários de excesso de otimismo que acompanham as fases ascendentes do ciclo de crédito, mas Weber contribui bastante para esclarecê-las combinando a análise crítica da literatura existente com um estudo detido das práticas de bancos de investimento, construtoras, investidores e agências de risco no auge do boom de Chicago.

Um segundo plano analítico, complementar, se abre quando Weber se volta para as práticas profissionais de uma miríade de agentes territorializados que garantiram a criação da demanda necessária para os novos edifícios. Com efeito, se há algo que surpreende no caso de Chicago, bem documentado pela autora, é o fato de que não existia demanda efetiva para tantos novos prédios corporativos, ao menos quando se consideram os indicadores convencionais para mensurar a demanda por ocupação (por exemplo, a criação de novos empregos no setor de serviços). Não obstante esse paradoxo, os novos lançamentos imobiliários continuaram a todo vapor durante os anos 2000. Ao explicar essa aparente contradição, Weber complementa a tradição da economia política com uma análise de viés institucional que procura situar as práticas dos agentes em contextos sociais, políticos e institucionais particulares, historicamente construídos e territorialmente circunscritos. Essa perspectiva é importante no livro porque permite à autora desvendar uma gama de práticas profissionais no domínio da corretagem imobiliária e de atividades correlatas (auditores, consultores, marketing etc.) responsáveis por "produzir" a demanda de imóveis novos - uma assertiva que contraria os preceitos dominantes da economia convencional, segundo os quais a oferta apenas refletiria fielmente uma demanda preexistente. Essas práticas envolvem, entre outras coisas, a difusão de uma determinada concepção de "obsolescência" que condena edifícios relativamente recentes a um status inferior, mesmo que, na prática, as inovações trazidas pela nova geração de edifícios não justifique essa distinção. $\bigcirc$ complemento necessário da ideia de obsolescência difundida por esses agentes são os signos de prestígio que aderem às novas localizações e aos edifícios mais novos, levando muitas empresas a mudar de endereço em busca de visibilidade e reputação. A construção social dessa preferência por prédios mais modernos é, para Weber, um fator fundamental para entender a continuidade dos lançamentos imobiliários na área central de Chicago mesmo quando já se 
vislumbravam os sinais de excesso de oferta - os empreendedores individuais sempre podiam racionalizar sua decisão de construir apelando para a crença de que haveria demanda para prédios novos por parte de empresas que ocupavam prédios antigos. Em resumo, a abundância de capital é apenas uma parte da história na análise de Rachel Weber: para compreender como esse capital excedente se materializa no espaço da cidade, é preciso destrinchar as complexas relações entre agentes públicos e privados locais, bem como o ambiente institucional que encerra suas ações. São estas últimas que efetivam a financeirização das cidades pela criação de uma espécie de "linha de montagem" de novos ativos financeiro-imobiliários, dificilmente discernível quando a análise fica circunscrita à escala macroeconômica.

Ainda que de modo geral uma leitura bastante agradável, o livro From boom to bubble deixa, ocasionalmente, a impressão de ser um pouco repetitivo, suscitando dúvidas sobre a necessidade de certas passagens ou mesmo capítulos para sustentar seu argumento central. Adicionalmente, Weber ainda discute, num capítulo final, possíveis instrumentos regulatórios que poderiam municiar os governos locais para limitar a ocorrência de bolhas imobiliárias e sobreprodução de imóveis - fenômenos que têm efeitos negativos muito sérios no desenvolvimento local. Por interessantes que sejam as sugestões de intervenção por meio de políticas públicas e mudanças regulatórias em diferentes escalas institucionais, a própria autora parece cética quanto à possibilidade de efetivá-las, concluindo que a sobreprodução deve retornar assim que o crédito voltar a ser abundante. Não obstante essas pequenas ressalvas, a articulação dos dois planos analíticos referidos acima robustece a análise de Weber, que se revela uma contribuição bastante original para a literatura sobre a produção das cidades na economia atual, crescentemente financeirizada. 